\title{
Photography in Social Science Research
}

\author{
Carlos Miguel Ferreira \\ Interdisciplinary Centre of Social Sciences - CICS.NOVA; \\ ISCTE -University Institute of Lisbon, \\ Estoril Higher Institute for Tourism and Hotel Studies, Portugal
}

\section{Sandro Serpa}

\author{
Department of Sociology, \\ Faculty of Social and Human Sciences, University of the Azores; \\ Interdisciplinary Centre of Social Sciences - CICS.UAc/CICS.NOVA.UAc; \\ Interdisciplinary Centre for Childhood and Adolescence - NICA -UAc, Portugal
}

DOI: https://doi.org/10.36941/jesr-2020-0o65

\section{Abstract}

Visual communication is critical in contemporary societies. Research in social sciences increasingly tends to mobilize the image, for example, in the form of photography, in its processes (in the collection and interpretation of information) and products (in the communication of research results), which leads to the need to reflect critically on its specificities. This paper aims to add to the analysis of the potentialities, limitations and challenges of the use of photography in social sciences research. For this purpose, the paper presents and discusses empirically collected documentary expressions, selected from an organizational case study based on their heuristic capacity to illustrate the argumentation put forth herein. It is concluded that the potential of the use of photography in research in social sciences is high, but it is essential that the researcher considers, besides more technical aspects and ethical complexities, that photography is, in part, also the materialization of a certain socially constructed representation of reality.

Keywords: photography, research, social sciences, memory, organization

\section{Introduction}

The importance of photography, whatever its kind, in portraying the world as realistic images, has been, and remains, critical. According to Hertzmann (2018), "Prior to the invention of photography, realistic images of the world could only be produced by artists" (p. 3). The members of contemporary societies are increasingly immersed in digital culture with the increase of visual communication in a multimedia context, through the use of the digital image in the context of their daily lives, in a process of increasing centrality of the photographic image in social life (Bastos, 2014; Fusari, 2017; Rossi, 2017; O'Hara \& Higgins, 2017; Cruz \& Salazar 2016; Sbriccoli, 2016; Strathman, 2015).

There are different types of photography, such as documentary, artistic and/or aesthetic photography (Neutra, 2014; Roberts, 2011), as well as photography that can mobilize, for example, new techniques and procedures, such as digital, drone and aerial photography (Asăndulesei, 2017; Roberts, 2011). In any case, two basic operations of photography remain: framing (which should be included in 
the photograph) and timing (when taking the photograph) (Bogdan \& Biklen, 1999).

The relationship between photography as an art and/or science has a very rich history (Hertzmann, 2018; Kemevor \& Essuman, 2017; Hamer, 2016; Roberts, 2011; Carbon, 2017; Bastos, 2014; Karpov \& Kryuchkov, 2015). Specifically on the relationship between photography and scientific knowledge (Vanti, 2006; Rios, Costa, \& Mendes, 2016; Roberts, 2011), Silva (2014) sustains that

Photography represented a breath in scientific activity, which began to incorporate, in its speculative strategies, a new heuristic principle, presenting itself as a new standard of rigor - when, in fact, the photographic image, at a single time, diverted attention from the text to itself and gave persuasive power to the whole of scientific discourse (p. 347).

It is not yet very common to mobilize photography in research (Silva, 2014), but there is a consensus that the interest in the use of visual instruments in social research has increased (Miller, 2015; Hamer, 2016; Fassetta, 2016; Langmann \& Pick, 2013; Roberts, 2011; Wang \& Dong, 2013; Lígia, 2005; Buchanan, 2001). There are several reasons for this increase in the interest of using photography in social research (O'Hara \& Higgins, 2017). The following factors, among others, can be highlighted: the fact that photographs can be taken by people with different cultural backgrounds, the wealth of information in a photograph, and the mass production of technological photography equipment that has made photography normality of our days (Wang \& Dong, 2013).

However, the mobilization of photography in social research raises specific difficulties, both at the level of collection and interpretation and in the communication of research results (Hamer, 2016). Issues arise in the processes (in the collection and interpretation of information) and research products (in the communication of research results). Among these issues, there is the validity of photography as an objective/subjective document, its interpretation, its role in the illustration of a text, its place in the crossing of information gathered through various techniques, and ethical aspects.

Photography as an unwritten document is more frequently used in research studies with a strong inductive component, which have a qualitative dimension whatever the variant of the type of research. In this kind of research, hypotheses in the strict sense of the term are not tested, but guided by objectives of understanding and/or changing a given situation in its complexity, such as research of discovery (Gómez, Flores, \& Jiménez, 1999; Yin, 2009), or action research with strong direct articulation between research and intervention (Serpa, Ferreira, Santos, \& Teixeira, 2018; Kia-Keating, Santacrose, \& Liu, 2017). Tuckman (2000) offers the following characteristics of qualitative research: "it develops in the natural situation, the researcher being the data collection tool. His main concern is to describe, referring to the process, analyzing the data inductively and worrying about the meaning of things" (p. 532). In short, this is to "study objectively the subjective states of their subjects" (Bogdan \& Biklen, 1999, p. 67) in a scientific way, as a set of verified and verifiable knowledge, obtained through a systematic process and demonstrated in a rigorous and controlled way, both in the process and in the product of the research (Ferreira \& Serpa, 2018).

In short, the status of photography in research is much debated and even controversial, whatever its origin - for example, whether or not taken specifically for research, or the intentional involvement of the researcher in obtaining the photograph and its interpretation. In most situations, photography functions more as a complement or triangulation element with information collected through other techniques (Bogdan \& Biklen, 1999; O’Hara \& Higgins, 2017; Wang \& Dong, 2013; Hamer, 2016; Faro, 2018).

This paper aims to add to the analysis of the potentialities, limitations and challenges of the use of photography in social science research. To this end, the authors will address the status of photography by directly following photography in research and the ethical aspects involved. For this purpose, the article presents and discusses two empirically collected documentary manifestations, selected from an organizational case study based on their heuristic capacity to illustrate the argumentation exposed here and justify the conclusions of this study. 


\section{Methods}

Research in social sciences increasingly tends to mobilize the image, for example, in the form of photography, in its processes (in the collection and interpretation of information) and products (in the communication of research results), which leads to the need to reflect critically on its specificities. This paper aims to add to the analysis of the potentialities, limitations and challenges of the use of photography in social science research. For this purpose, two empirically collected documentary manifestations, selected from an organizational case study (Serpa, 2013, 2015, 2017; Lemos, 1958; Lima, 1981; Macedo, 1981), are presented and discussed, based on their heuristic capacity to illustrate the argumentation presented here.

The chosen case is aligned with the research object and, consequently, the qualities that are acknowledged are theoretical in nature. These qualities, made explicit from a disciplinary perspective, from a specific point of view, give representativeness to the case. This representativeness does not come from statistics, which it is often reduced to in sociology, but from representativeness that can be qualified as theoretical or sociological (Hamel, 1997a, 1997b).

The "relational" nature of the notion of "case" is emphasized. For an object of study to be a "case", it must be linked to a double theoretical and historical context (Wieviorka, 1992; Hamel, 1998; Latzko-Toth, 2009). The case study leads to an in-depth study, having as relevant features: (i) the intensity of the approach linked to the multiplicity of facets to study in the analysis of the research unit and depth of the study; (ii) the flexibility in the selection and use of techniques; and (iii) the volume and heterogeneity of the information collected (Greenwood, 1965).

\section{Results and Discussion}

Cruz and Salazar (2016) maintain that "An important objective of the photographic act is the creation of future memories", both individually and in collective memory (Drainville, 2018; Rizzia Rocha, 2018; Felipe \& Pinho, 2018; Serpa, 2017; Halbwachs, 1990). The role of photography can then be central in (re)defining a given reality (true, false or undefined, highlighting only some aspects of a reality that is, itself, always complex), for political, social and/or ideological reasons.

An illustration is offered below, with the following document that was given to the guests at the commemoration, in 1958, of the centenary of the Asylum for Disadvantaged Children of Horta (a shelter institution for underprivileged girls in the city of Horta, the Azores, Portugal) (Serpa, 2017) (Figure 1).

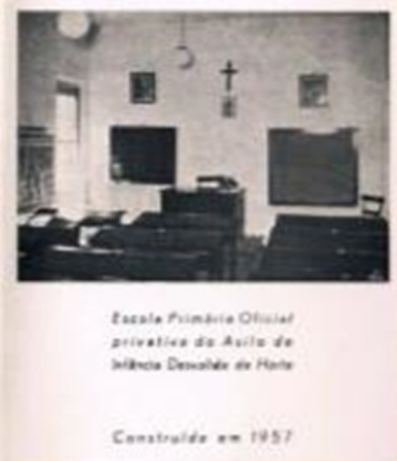

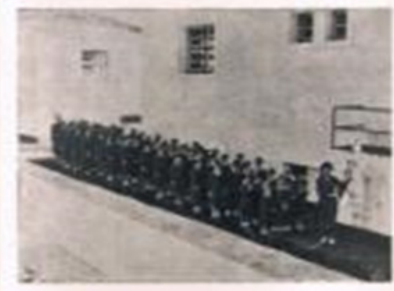

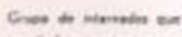

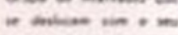

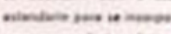
orom nus bile nivese

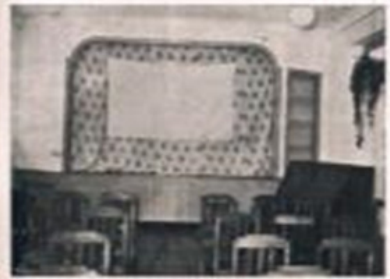

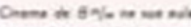

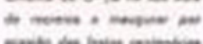



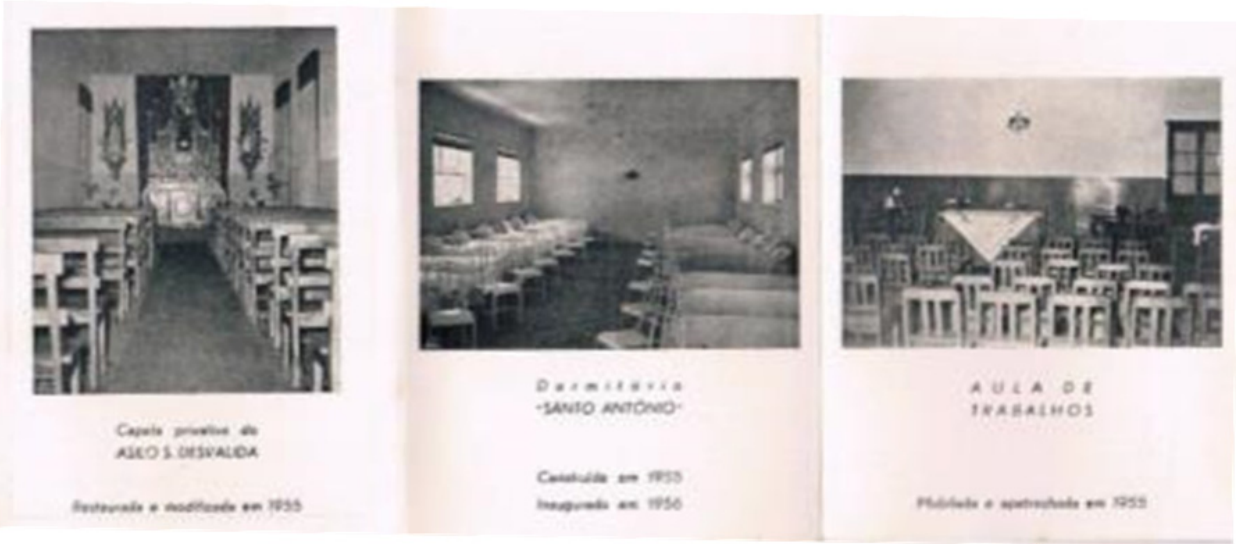

teasation

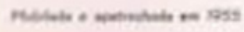

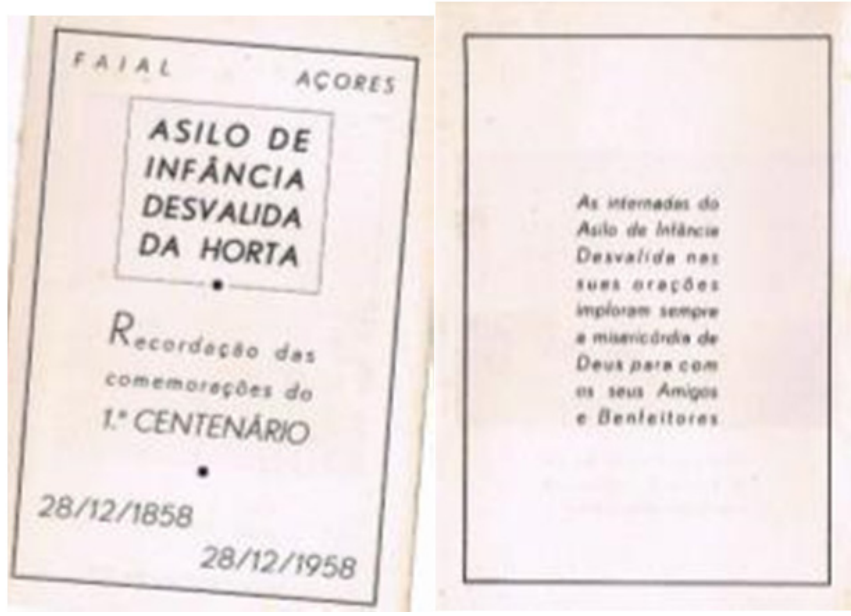

Figure 1: Asylum photographs

Source: Remembrance of the ist Centennial Celebrations of the Asylum for Disadvantaged Children of Horta

Figure 1 - with the various photographs that explicitly show order, cleanliness, religiosity and improvements in the facilities - depicts the importance of conveying a positive external image of the organisation in the promotion of a good relationship with the surrounding environment, in the promotion of internal cohesion and, finally, in the published institutional image. In this case, it is safe to conclude that this celebration worked as a celebration of the success of this organization, materialized in its institutional identity, making memory a fundamental resource in this process. These results led to the recognition of the importance of the mobilization of memory in the process of legitimizing an organization (Serpa, 2017).

All photography is, by its very nature, manufactured, more or less intentionally, either considering the purposes ascribed to it or the level of technical procedures in the photographer's own framing and relationship with those photographed (Vanti, 2006; Langmann \& Pick, 2013; Cruz \& Salazar, 2016; Roberts, 2011). Vanti (2006) argues that photography

[...] may suffer connotation procedures such as trucking (retouching, approaching or distancing from elements present in the image, etc.), posture (tested posture of the subjects captured by the lens), 
inclusion of objects (inclusion of objects that characterize the moment or message that the photographer wants to represent), photogeny (the image embellished by techniques of lighting, printing and printing), aestheticism (when photography is intended to be art, painting, as in the case of early twentieth century pictorialism) and syntax (when we have photographs in sequence, where the unit of reading is the very sequence and not the fragments of it)" (p. 129).

Photography is both a cultural product and a cultural producer (Bogdan \& Biklen, 1999, p. 191). There is the challenge - and, simultaneously, the need - to be aware of the production conditions of photography (Silva, 2014) as a representation of the real object (Fusari, 2017), placing photography in its own context (Bogdan \& Biklen, 1999; Wang \& Dong, 2013; Rios et al., 2016; Roberts, 2011; Drainville, 2018; Carbon, 2017). For example, who took the photograph, the researcher or other people, and the researcher's choice (Roberts, 2011). On this issue, Borges (2005) comments that "When do we ask where? when? how? why? with whom? and for what purposes the photographic representations were and/or are produced, disseminated and incorporated, we are actually contextualizing their production, dissemination and consumption processes" (p. 47).

The mobilization of photography in research can be more or less invasive (Asăndulesei, 2017), which, besides raising technical problems of collection and analysis of photography, also raises ethical problems (Gómez et al., 1999; Lima, 2006; Bogdan \& Biklen, 1999; Ferreira \& Serpa, 2018; Langmann \& Pick, 2013) and even legal issues (Roberts, 2011), specifically with the use of photography (Kia-Keating et al., 2017; O'Hara \& Higgins, 2017; Miller, 2015). Wang and Dong (2013), referring to Wang and Redwood-Jones (2001), mention the following five ethical issues:

(1) photographing individuals in public spaces may be legal but is not ethically neutral; (2) photographing individuals within public space can be interpreted as an invasion of privacy and an intrusion into their private space; (3) this method carries the possibility of doing harms to participants for they may photograph someone without his or her consent and suffer retaliation; (4) there are issues of ownership and they argue that the author of the photographs should remain the true owner of both prints and negatives; and finally, (5) there is the possibility of the researcher influencing thematic content (p. 9o).

\section{Conclusion}

The commemorative photographs of the centenary of the Asylum for Disadvantaged Children of Horta express representation of the symbolic world of the asylum institutions and the multiple interior and exterior standpoints on these shelter establishments aimed at disadvantaged children. Consequently, photographs may be understood as documents, as "means of communication", produced for some purpose and goal. It is important to understand who produced them, their purpose, whom they were created for, and the intentionality of their production. They may be understood as a way of contextualizing information and analyzed as communicative devices methodologically developed in the production of versions about events (Flick, 2005). Considering that documents are instruments and communication supports, which express objectified forms of experiences and knowledge related to a given sector of the human practices, it follows that the whole document is contextualizable within a given social and cultural framework. In this framework marked by its complexity, the document is part of the framework of social relationships and takes on a given role in the game of social relationships, ascribing value to acts or shaping relationships (Lalanda-Gonçalves, 2014).

The spontaneous representations of photography refer to its instrumental nature, whose capacity - inherent to its technique - of "accurate" representation of reality gives it a documentary nature and make it seem that it is a process of faithful and impartial reproduction of social life. Albeit closely linked to the recording of evidence, it has only fictional objectivity. The photographic practice is subject to a "collective rule"; thus, the "most insignificant" photograph expresses the system of the perception, thought and appreciation schemes that are common to a given group. It can inform not only about the situation and position occupied by one or more individuals involved in the image 
capture process, but it also creates a direct link with socially shared schemes that inform both about individual aspects of the agents' actions and experiences, and their social conditions and trajectories (Ferro, 2005; Bourdieu et al., 1990; Bourdieu \& Bourdieu, 2004; Pontes, 2014; Martins, 2008).

In short, the ideological relationship between art, culture and the politics of photography should be considered (Pfautsch, 2018; Lee, 2016; Miller, 2015). Buckley (2018) argues that "Images can always be turned. And it is precisely their capacity to turn and to be turned that makes photographs of war such formidable and at the same time, such unreliable weapons" (p. 24).

The results of this analysis allow concluding, then, that there is a high potential for the use of photography in research, but it is critical that the researcher considers aspects such as the collection and interpretation of photography as a socially constructed representation, as well as the ethical complexities of mobilizing photography. This stance is not trying to convey a pessimistic image of the use of photography in research and does not intend to be contrary to the popular saying: an image is not always worth more than a thousand words. Yet, the picture does not speak for itself.

\section{Acknowledgements}

University of the Azores, Interdisciplinary Centre of Social Sciences-CICS.UAc/CICS.NOVA.UAc, UID/SOC/04647/2020, with the financial support of the FCT/MEC through national funds and when applicable co-financing from the FEDER under the PT2020 Partnership Agreement.

\section{References}

Asăndulesei, A. (2017). Inside a Cucuteni settlement: Remote sensing techniques for documenting an unexplored eneolithic site from northeastern Romania. Remote Sensing, 9(1), 41. https://doi.org/10.339o/rs9o10041

Bastos, A. R. (2014). The photograph as a portrait of society. Sociology. Revista da Faculdade de Letras da Universidade do Porto, XXVIII, 127-143.

Bogdan, R., \& Biklen, S. (1999). Qualitative research in education: An introduction to theory and methods. Porto: Porto Editora.

Borges, M. E. L. (2005). Fotografia: Desafios da interdisciplinaridade [Photography: Challenges of interdisciplinarity]. Estudos Ibero-Americanos, 31(2), 41-51. http://dx.doi.org/10.15448/1980-864X.2005.2.1337

Bourdieu, P. et al. (1990). Photography: a middle-brow art. Cambridge: Polity Press.

Bourdieu, P., \& Bourdieu, M-C. (2004). The peasant and photography. Ethnography, 5(4), 6o1-616.

Buckley, B. (2018). The politics of photobooks: From Brecht's war primer (1955) to Broomberg \& Chanarin's war primer 2 (2011). Humanities, 7 (2), 34. https://doi.org/10.3390/h7020034

Buchanan, A. (2001). The role of photography in organization research. A reengineering case illustration. Journal of Management Inquiry, 10(2), 151-164. https://doi.org/10.1177/1056492601102018

Carbon, C. C. (2017). Universal principles of depicting oneself across the centuries: From Renaissance self-portraits to selfie-photographs. Frontiers in Psychology, 8. https://doi.org/10.3389/fpsyg.2017.00245

Cruz, N. V., \& Salazar, M. (2016). Fotografar prejudica a memória? [Does taking photographs impair memory?] Photographic Speeches, 12(21), 13-32. http://dx.doi.org/10.5433/1984-7939.2016v12n21p13

Drainville, R. (2018). Iconography for the age of social media. Humanities, $7(1)$, 12. https://doi.org/10.3390/h7010012

Faro, L. (2018). When children participate in the death ritual of a parent: Funerary photographs as mnemonic objects. Religions, 9(7), 215. https://doi.org/10.3390/rel9070215

Fassetta, G. (2016). Using photography in research with young migrants: Addressing questions of visibility, movement and personal spaces y in research with young participants. Children's Geographies, 14(6), 701-715, https://doi.org/10.1080/14733285.2016.1190811

Felipe, C. B. M., \& Pinho, F. A. (2018). Fotografia como dispositivo da memória institucional [Photography as an institutional memory device]. Logeion: Filosofia da Informação, 5(1), 89-101. https://doi.org/10.21728/logeion.2018v5n1.p89-101

Ferreira, C. M., \& Serpa, S. (2018). Informed consent in social sciences research: Ethical challenges. International Journal of Social Science Studies, 6(5), 13-23. https://doi.org/10.11114/ijsss.v6i5.3106

Ferro, L (2005). Ao encontro da sociologia visual [Towards visual sociology]. Sociologia, 15, 373- 398. 
Flick, U. (2005). Métodos qualitativos na investigação científica [Qualitative methods in scientific research]. Lisboa: Edições Monitor.

Fusari, M. (2017). From the photograph to the meta-image my practice-led search for a new digital epistemology. Proceedings, 1(9), 889. https://doi.org/10.3390/proceedings1o9o889

Gómez, G. R, Flores, J. G., \& Jiménez, E. G. (1999). Qualitative research methodology. Archidona: Ediciones Aljibe.

Greenwood, E. (1965). Métodos de investigação empírica em sociologia [Empirical research methods in sociology]. Análise Social, 11, 313-345.

Halbwachs, M. (1990). Collective memory. São Paulo: Edições Vértice and Editora Revista dos Tribunais, Ltda.

Hamel, J. (1997a). Étude de cas en sciences sociales [Case study in social sciences]. Paris: L'Harmattan.

Hamel, J. (1997b). Précis d'épistémologie de la sociologie [Summary of epistemology of sociology]. Paris: L'Harmattan.

Hamel, J. (1998). Défense et illustration de la méthode des études de case en sociologie et anthropologie. Quelques notes et rappels [Defense and illustration of the method of case studies in sociology and anthropology. Some notes and reminders]. Cahiers Internationaux de Sociologie, 104, 121-138.

Hamer, C. (2016). A collaborative methodology between photography and performance in ethnographically informed research. Critical Arts, 30(3), 341-356. https://doi.org/10.1080/02560046.2016.1205321

Hertzmann, A. (2018). Can computers create art? Arts, 7(2), 18. https://doi.org/10.3390/arts7020018

Karpov, D., \& Kryuchkov, Y. (2015). Analytical photography as a new tool for the representations of reality. Procedia - Social and Behavioral Sciences, 166, 675-679. https://doi.org/10.1016/j.sbspro.2014.12.595

Kemevor, A. K., \& Essuman, J. (2017). The institutionalization of photographic industry and the society. The Journal of Social Sciences Research, 3(2), 13-19. Retrieved from https://arpgweb.com/pdf-files/jssr3(2)1319.pdf

Kia-Keating, M., Santacrose, D., \& Liu, S. (2017). Photography and social media use in community-based participatory research with youth: Ethical considerations. American Journal of Community Psychology, 6o(34), 375-384. https://doi.org/10.1002/ajcp.12189

Lalanda-Gonçalves, R. (2014). O documento nas ciências sociais: Construção e contextos sociais. In As transformações do documento no espaço-tempo do conhecimento [Les transformations du document dans l'espace-temps de la connaissance]. III Colóquio Internacional da Rede MUSSI [III Colloque International du Réseau MUSSI], November 10-12.

Langmann, S., \& Pick, D. (2013). Dignity and ethics in research photography. International Journal of Social Research Methodology, 17(6), 709-721. https://doi.org/10.1080/13645579.2013.825473

Latzko-Toth, G. (2009). L'étude de cas en sociologie des sciences et de techniques [The case study in sociology of science and technology]. Montréal: CIRST, Université du Québec à Montréal.

Lee, J. (2016). Presidents visual presentations in their official photos: A cross-cultural analysis of the US and South Korea. Cogent Arts \& Humanities, 3(1). https://doi.org/10.108o/23311983.2016.1201967

Lemos, R. R. G. (1958). Asylo da Horta [Asylum of Horta]. 1858-1958. Handwritten work celebrating a century of existence.

Lígia, F. (2005). Ao encontro da sociologia visual. Sociologia. Porto: Faculdade de Letras da Universidade do Porto.

Lima, J. Á. (2006). Ethics in research. In J. Á. de Lima, \& J. A. Pacheco (Eds.), Doing research (pp. 127-159). Porto: Porto Editora.

Lima, M. (1981). Annals of Horta Municipality (History of the Faial Island). East Providence: A \& H Printing, Inc.

Macedo, A. L. S. (1981). History of the four islands that form the District of Horta (III Volume). Angra do Heroísmo: Regional Directorate of Cultural Affairs of the Regional Secretariat of Education and Culture of the Autonomous Region of the Azores (Facsimile reprint of the 1st original edition of 1871 ).

Martins, J. (2008). Sociologia da fotografia e da imagem [Sociology of photography and image]. São Paulo: Contexto.

Miller, K. (2015). Dear critics: Addressing concerns and justifying the benefits of photography as a research method. Forum Qualitative Sozialforschung/Forum: Qualitative Social Research, 16(3), Art. 27. 1-17. Retrieved from http://www.qualitative-research.net/index.php/fqs/article/view/2434/3875

Neutra, R. (2014). On the past and future tensions between documentation and esthetics in architectural photography. Arts, 3(3), 335-349. https://doi.org/10.3390/arts3030335

O’Hara, L., \& Higgins, K. (2017). Participant photography as a research tool. Sociological Methods E Research. https://doi.org/10.1177/oo49124117701480

Pfautsch, A. (2018). Documentary photography from the German Democratic Republic as a substitute public. Humanities, 7(3), 88. https://doi.org/10.3390/h7030088 
Pontes, N. (2014). Os motivos de tais fotografias: Os usos sociais da fotografia para uma leitura sociológica do mal [The reasons for such photographs: The social uses of photography for a sociological reading of evil]. Política \& Trabalho, Revista de Ciências Sociais, 40, 257-275. Retrieved from https://periodicos.ufpb.br/ojs/index.php/politicaetrabalho/article/view/20155

Remembrance of the commemorations of the ist Centennial Asylum of Invalid Childhood in Horta (1958).

Rios, S. O., Costa, J. M. A., \& Mendes, V. L. P. S. (2016). Photography as a technique and object of study in qualitative research. Photographic Speeches, 12(20), 98. http://dx.doi.org/10.5433/1984-7939.2016v12n2op98

Roberts, B. (2011). Photographic portraits: Narrative and memory. Forum Qualitative Sozialforschung/Forum: Qualitative Social Research, 12(2), Art. 6. Retrieved from http://www.qualitativeresearch.net/index.php/fqs/article/view/1680/3204

Rizzia Rocha, R. (2018). A fotografia como dissolução e escrita da memória [Photography as dissolution and writing of memory]. Doispontos, 15(2), 33-40. http://dx.doi.org/10.538o/dp.v15i2.62699

Rossi, D. (2017). Shaping virtual image. Proceedings, 1(9), 961. https://doi.org/10.3390/proceedings1090961

Sbriccoli, T. (2016). Between the archive and the village: The lives of photographs in time and space. Visual Studies, 31(4), 295-309. https://doi.org/10.1080/1472586X.2016.1243931

Serpa, S. (2013). Celebrations and language on the image of Asilo de Infância Desvalida da Horta, Portugal, 18581910. Revista de Ciências Humanas, 47(2), 331-343. https://doi.org/10.5007/2178-4582.2013V47n2p331

Serpa, S. (2015). A sociological approach to institutional communication: The public image in organizational administration in education. International Education Studies, 9(1), 79. http://dx.doi.org/10.5539/ies.v9n1p79

Serpa, S. (2017). Memory in the celebration of organisational identity. The International Journal of Interdisciplinary Organizational Studies, 12(2), 23-33. https://doi.org/10.18848/2324-7649/CGP/v12io2/23-33

Serpa, S., Ferreira, C. M., Santos, A. I., \& Teixeira, R. (2018). Participatory action research in higher education training. International Journal of Social Science Studies, 6(6), 1-7. https://doi.org/10.11114/ijsss.v6i6.3286

Silva, J. R. (2014). Fotografia e ciência: A utopia da imagem objetiva e seus usos nas ciências e na medicina [Photography and science: The utopia of objective image and its uses in the sciences and medicine]. Bulletin of the Emílio Goeldi Museum of Pará. Humanities, 9(2), 343-36o. https://doi.org/10.1590/198181222014000200006

Strathman, N. (2015). Student snapshots: An alternative approach to the visual history of American Indian boarding schools. Humanities, 4(4), 726-747. https://doi.org/10.339o/h4040726

Tuckman, B. W. (200o). Handbook of research in education. Lisbon: Calouste Gulbenkian Foundation.

Vanti, E. S. (2006). Photography and research in Educational History: Elements for the construction of a methodology. History of Education, 19, 121-130. Retrieved from https://seer.ufrgs.br/asphe/article/view/29407/pdf

Wang, Y., \& Dong, H. (2013). Exploring photography as a method for research. 2013 IEEE Tsinghua International Design Management Symposium. https://doi.org/10.1109/TIDMS.2013.6981220

Wieviorka, M. (1992). Case studies: History or sociology? In C. Ragin, \& H. Becker (Eds.), What is a case? Exploring the foundations of social inquiry (pp. 159-172). New York: Cambridge University Press.

Yin, R. K. (2009). Case study research: Design and methods. Los Angeles: SAGE. 